\title{
Alternatives for the treatment of transfer pricing adjustments in South Africa
}

\author{
Lana Harmse \\ MCom Taxation, South African Professional Accountant (SAIPA) \\ Senior lecturer, School of Accounting Sciences, North-West University \\ Pieter van der Zwan \\ MCom Taxation, Chartered Accountant (SA) \\ Associate Professor, School of Accounting Sciences, North-West University
}

\begin{abstract}
OPSOMMING
Alternatiewe vir die hantering van oordragprysaansuiwerings in Suid-Afrika

Die Inkomstebelastingwet maak tans voorsiening vir 'n geagte dividend as sekondêre aanpassing wanneer 'n maatskappy 'n oordragsprysaansuiwering ingevolge artikel 31 maak. Gegewe die feit dat hierdie bepaling drie keer in die afgelope vier jaar gewysig is, ondersoek hierdie artikel die bepaling om vas te stel of dit konseptueel suiwer is of bloot 'n praktiese maatreël wat in die toekoms verdere wysigings sal noodsaak. Die konseptuele ontleding is gebaseer op die karaktereienskappe van die alternatiewe transaksies waarop sekondêre aanpassings gebaseer word, die vereistes van verbondenheid van persone asook nie-belasting motiewe wat oordragsprysing beïnvloed. Uit die ontleding blyk dit dat die hantering van sekondêre aanpassings normaalweg wel konseptueel suiwer is, behalwe in die geval waar 'n Suid-Afrikaanse beherende maatskappy 'n oordragsprysaanpassing maak wat voortspruit uit 'n transaksie met 'n beheerde maatskappy. Daar word aangevoer dat die moontlikheid van 'n dubbele dividendbelastingimplikasie 'n uitsondering op die sekondêre aanpassing reël vir maatskappye kan regverdig.
\end{abstract}

\section{Introduction}

The manipulation of pricing in international trade that leads to capital flight and tax base erosion has long been a concern of governments. ${ }^{1}$ Transfer pricing concerns arise when a local company undercharges for its supply of goods and services to connected offshore parties, or is overcharged for goods and services it acquires from such parties. In both

1 OECD Transfer pricing guidelines for multinational enterprises and tax administrators (2010) 17; De Boyrie et al. 'Estimating the magnitude of capital flight due to abnormal pricing in international trade' 2005 Accounting Forum 249. 
instances, the result is a reduction of its taxable profits. ${ }^{2}$ Transfer pricing adjustments address the potential mismatch between the profit allocation for tax purposes and the distribution of risks, assets and functions between related parties. ${ }^{3}$ In the South African context, the transfer pricing provisions in section 31 of the Income Tax $\mathrm{Act}^{4}$ aim to prevent this reduction in taxable income. Taxpayers are required to adjust their taxable income to reflect arm's length amounts if they enter into transactions with connected persons outside South Africa on terms or conditions that are not at arm's length and derive a tax benefit from such terms and conditions. Section 31 (2) requires a primary adjustment to correct the direct impact of non-arm's length pricing on the taxable income of a South African taxpayer by increasing such taxable income. ${ }^{5}$ The shifting of value through artificial pricing may however also provide taxpayers with an opportunity to avoid other tax implications - for example, withholding taxes on distributions, in the host country. ${ }^{6}$ In order to adjust the overall tax effect of the value allocation to what it would have been had it not been for the non-arm's length pricing arrangement, the domestic tax law of a country may require a further adjustment, which is commonly referred to as a secondary adjustment. ${ }^{7}$

Prior to the amendments of section 31 in 2012, a secondary adjustment existed in the form of a deemed dividend that was subject to Secondary Tax on Companies. Section 31 was amended to deem a primary adjustment to give rise to a notional loan, which was in turn deemed to be an affected transaction that required a further adjustment to taxable income due to the lack of interest charged on this notional loan. ${ }^{8}$ With effect from 1 January 2015 , section $31(3)$ was again amended due to the concerns regarding the administrative burden on taxpayers and the tax authorities as well as complications in respect of exchange controls caused by the notional loan. ${ }^{9}$ This section now deems a resident company to have paid a dividend if a transfer pricing adjustment arises between itself and a connected non-resident or another resident's permanent establishment outside of South Africa.

2 SARS Practice Note 7: Section 31 of the Income Tax Act, 1962 (the Act): Determination of the taxable income of certain persons from international transactions: Transfer pricing (1999) 5; OECD supra $\mathrm{n} 1$ at 19; Kotze 'Internal transfer pricing, be careful, very careful' 2011 TaxTalk 16-17.

3 OECD Multi-country analysis of existing transfer pricing simplification measures (2012) 14.

458 of 1962 , hereinafter the Act (any reference to a section in this article refers to a section in the Act unless specifically indicated otherwise).

5 OECD supran 3 at 14.

6 European Commission Final report on Secondary Adjustments Directorate General Taxation and Customs Union (2013) 3.

7 OECD supra $n 1$ at 28.

8 Section 57 of the Taxation Laws Amendment Act 24 of 2011; National Treasury Explanatory memorandum on the Taxation Laws Amendment Bill 2014 (2014) 61

9 Section 50 of the Taxation Laws Amendment Act 43 of 2014. 
Given the number of changes to the secondary adjustment and in particular the change back to a deemed dividend - a position which warranted an amendment to a deemed loan in 2012 - the question arises whether the 2015 amendment is conceptually sound or merely a temporary practical expedient that may ultimately require further amendments. The aim of this article is to consider whether the nature of the secondary adjustment to be made by a resident company is conceptually sound. The basis for the conceptual analysis is provided in part 2 of the article. The conceptual analysis that was performed is reported in part 3 and the article concludes with findings and recommendations in part 4.

\section{Basis for the Conceptual Analysis of Section 31(3)(i)}

The conceptual analysis of section 31(3)(i) was based on the main requirements that impact on the application of the section. In addition, the alternatives suggested for the potential treatment of the adjustment were taken into consideration. The characteristics of each of the underlying transactions on which the hypothetical adjustment can be based are considered in paragraph 21 below. The relationships that result in persons being connected to a company and therefore potentially subject to transfer pricing adjustments are explored in paragraph 22 . Lastly, the reasons and motives affecting pricing between related parties as evidenced in the literature are discussed in paragraph 23.

\section{Nature of the Underlying Transactions}

The Organisation for Economic Co-operation and Development (OECD) identified a dividend, loan (debt) and equity contribution as the most common constructive transactions as a basis for secondary adjustments. ${ }^{10}$ The critical and distinguishing characteristics of each of these three transactions are identified in this part of the article based on definitions in the Act and other relevant legislation as well as case law, all of which may provide a legal perspective on the nature of the underlying transaction. The analysis is expanded to also include International Financial Reporting Standards (IFRS), which often classifies a transaction or event on its substance as opposed to its legal form. ${ }^{11}$

\section{Dividend}

A dividend is defined in section 1 as:

any amount transferred or applied by a company that is a resident for the benefit or on behalf of any person in respect of any share in that company, whether that amount is transferred or applied -

10 OECD supran 1 at 28.

11 International Accounting Standards Board (IAS) Conceptual Framework for Financial Reporting (2010) 26. 
(a) by way of a distribution made by; or

(b) as consideration for the acquisition of any share in, that company.

This definition excludes certain transfers that meet these requirements if made from capital (in the context of the Act, this is referred to and defined in section 1 as contributed tax capital).

The definition of a dividend does not limit the counterparty to whom the benefit is transferred to a shareholder as it refers to any person. A shareholder does not have to receive the benefit personally but may also benefit from amounts flowing to another entity under its control. ${ }^{12}$ The Companies Act's ${ }^{13}$ definition of a distribution similarly refers to a transfer of money or property to or for the benefit of the shareholder of such company or any other company in a group scenario.

The term 'amount' includes anything that has a monetary value. ${ }^{14}$ It is submitted that this view may be of particular relevance to a transfer pricing adjustment as it was expressed in the context of a transaction where a benefit (use of funds without paying interest) was derived without being realised in cash. This scenario has some similarities to a transfer pricing adjustment where goods or services exceeding the cash consideration are transferred to the counterparty. The term amount, in the context of a dividend, may also include the transfer of property or another benefit (for example, the right of use of the property) for consideration less than its market value, as this represents value transferred by a company to or on behalf of a shareholder. ${ }^{15}$

A characteristic of a dividend, which is implied in the above discussion, is that the transfer of the amount contemplated should not involve any consideration in exchange for the transfer from the counterparty. ${ }^{16}$ This excess value over consideration paid (if any) constitutes a distribution from earnings and profits, ${ }^{17}$ which is in line with the IFRS definition of a dividend being a distribution of profits. ${ }^{18}$ In the context of a transfer pricing manipulation, the implicit profit extraction is evident from the fact that a transaction at arm's length would have left the company with greater distributable profits.

Therefore, it is submitted that a dividend represents an extraction of something of value from the company, ${ }^{19}$ whether cash or otherwise, in

12 Shedd v Commissioner of Inland Revenue (CIR) 2000 TC Memo 292 p 15.

1371 of 2008, hereinafter the Companies Act.

14 Brummeria Renaissance (Pty) Ltd v CSARS 2007 (69) SATC 205 p 213.

15 Cliffe Dekker Hofmeyr Large corporates and their tax advisers in the crosshairs? Sale of asset for less than market value: a dividend? (2012) 4 available from http://www.cliffedekkerhofmeyr.com/export/sites/cdh/en/news/publi cations/2012/tax/downloads/Tax_Alert_-11_May_2012.pdf (accessed 201306-02).

16 Shedd $v$ CIR supra $\mathrm{n} 12$ at 15.

17 Helminen The dividend concept in international tax law (1999) 1.

18 International Accounting Standard (IAS) 18 Revenue at par 5.

19 Jenks 'Constructive dividends resulting from section 482 adjustments' 1970 Tax Lawyer 84. 
a manner that a shareholder of the company, directly or indirectly, benefits through another related entity without the distributing entity receiving equivalent consideration in exchange for the value so transferred.

\section{Equity Contribution}

Unlike the term 'dividend', the Act does not directly refer to the term of an equity contribution. It however alludes to this concept in the definition of 'contributed tax capital' in section 1, which essentially refers to an amount of consideration received for the issuing of shares in the company. Similarly, the Companies Act does not explicitly refer to an equity contribution or capital, but makes provision for consideration to be paid for the subscription of shares in sections 39 and 40. In economic terms, the concept of equity contribution generally refers to funds invested in a company. ${ }^{20}$ Such funds invested would be exposed to the risk of the business, as opposed to loans that are only exposed to credit risk. $^{21}$ Unlike debt, capital would not ordinarily be returned to the investor in the normal course of the business. ${ }^{22}$ An investor, in contrast to a lender, profits through the growth of the business in the form of dividends or share value growth and will not necessarily withdraw funds in advance. ${ }^{23}$

In addition, the withdrawal of such an equity contribution is generally at the discretion of the company, in contrast to a loan that has fixed and enforceable repayment terms. For financial reporting purposes, a financial instrument is classified as an equity instrument - the financial reporting equivalent of an equity contribution - if the instrument includes no contractual obligation to deliver cash or other financial assets to another entity. ${ }^{24}$ Equity is distinguished from a financial liability by the fact that the entity cannot avoid making repayments to settle a contractual obligation relating to a liability, while any payment made in respect of an equity instrument can be avoided and, therefore, are at the discretion of the company. ${ }^{25}$

Therefore, it is submitted that the defining characteristics of an equity contribution is that it constitutes the transfer of property or funds by an investor (owner) to a company, where such company is under no obligation to repay such investment to the investor but may do so at its own discretion. In addition, the investor shares in the growth of the business of the company but is also exposed to the risk of the business.

20 Sage Holdings Ltd $v$ The Unisec Group Ltd 1982 (1) SA 337 (W) p 303.

21 Schlemmer $v$ Viljoen 1958 (2) SA 280 (T) p 288.

22 Ibid.

23 Keyes Federal taxation of financial instruments and transactions (2013) 1.

24 IAS 32 Financial Instruments: Classification and Presentation at par 11

25 IFRS A guide through International Financial Reporting Standards (2012) 956. 


\section{$213 \mathrm{Debt}$}

Neither the Act nor the Companies Act defines the terms 'loan' or 'debt'. The ordinary meaning of a loan is 'a thing that is borrowed, especially a sum of money that is expected to be paid back with interest'. ${ }^{26}$ A loan would generally contain stipulations regarding interest and capital repayments. $^{27} \mathrm{~A}$ further important trait of a loan is that it has an unconditional, fixed or definite obligation to repay a sum on a set date, along with a fixed percentage of interest, normally regardless of the debtor's profitability or lack thereof. ${ }^{28}$ This characteristic is supported by the financial reporting definition of a liability which requires a contractual obligation to deliver cash, or another financial asset, to another entity or to exchange financial assets or financial liabilities with another entity under conditions that are potentially unfavourable to the entity that has the liability. ${ }^{29}$ Unlike an equity instrument, the classification of an instrument as a financial liability requires that the entity has an unavoidable unconditional obligation to make repayments. In order to ensure that these obligations are met, the counterparty (lender) would generally prefer not to have a subordinated claim ${ }^{30}$ and may require security or collateral to ensure enforcement of the obligation. ${ }^{31}$ This feature of compulsory repayment is clearly distinguishable from the discretionary nature of payments made in respect of equity instruments that are likely to only be made if the borrower is in a position to make such repayments.

It is therefore submitted that the distinguishing characteristics of debt (loans), as opposed to a dividend or equity contribution, is the unavoidable requirement to repay the benefit or funds transferred, irrespective of the financial position of the entity.

\section{Relationships Covered by Section 31(3)(i)}

Section 31(3)(i) applies to a resident company transacting with a nonresident (including a controlled foreign company, as defined in section 9D) or a foreign permanent establishment of another resident that is connected to the first mentioned resident company. In this part of the conceptual analysis the connected person relationship, which is a prerequisite for a primary adjustment that may ultimately trigger a secondary adjustment, is considered. Literature on the composition of multinational groups as well as the definition of a connected person in the Act is the basis for the analysis.

26 The Oxford University Press Dictionary (2013).

27 Schlemmer $v$ Viljoen supra $\mathrm{n} 21$ at 288.

28 Curry v United States 1968396 F2d 630, 634 (5th Cir) par 634.

29 IAS 32 Financial Instruments: Classification and Presentation at par 11.

30 Nestle Holdings Inc. v CIR 90 TC 682 (1995) p 17.

31 Roth Steel Tube Co. v CIR 800 F2d at 630 (6th Cir. 1986) p 4. 


\section{Composition of Multinational Groups of Companies}

A multinational group consists of a parent corporation in the home country and operates through affiliates, whether in the form of branches or separately incorporated subsidiaries, in host countries. ${ }^{32}$ These affiliates operate in an interlocking network of activities and would work more or less in tandem depending on the control exercised by the parent company. ${ }^{33}$ Subsidiaries generally enjoy some degree of freedom from the control of the parent, but are ultimately required to contribute to the objectives of the group as a whole. ${ }^{34}$ As a result the behaviour of each entity is subject to the multinational group's unified control, compatible with a certain degree of decentralised decision making that could be deliberately allowed by the parent company to achieve certain commercial outcomes. ${ }^{35}$ Ownership requirements in various locations, for example, Broad-based Black Economic Empowerment in South Africa, may cause minority interests to exist in a multinational group. A layered structure where the ultimate control and concentration of value is separated from the operational activities may often exist to limit, or hollow out, the value being attributed to the minorities. ${ }^{36}$

Literature on the composition of multinational groups clearly distinguish between entities with a controlling role and those with an operational role. The structure of a multinational group typically involves a central ownership structure from which control is exercised over foreign affiliates. ${ }^{37}$ Research shows that multinational group structures tend to use pyramidal structures with the ultimate owner or group of owners controlling a structure of operational companies. ${ }^{38}$ This control may be concentrated in a group of persons including the state, entrepreneurs or families. ${ }^{39}$ Functions performed at the controlling level of a multinational group structure include capital decision making,

32 Kopits Taxation and multinational firm behaviour: a critical survey (1976) 626.

33 Eden Taxing Multinationals: Transfer pricing and corporate income taxation in North America (1998) 6.

34 Sakurai 'Comparing cross-cultural regulatory styles and processes in dealing with transfer pricing' 2002 International Journal of the Sociology of Law 176.

35 Kopits supra $\mathrm{n} 32$ at 627.

36 Naiping et al. 'A Regression Analysis on Ultimate Shareholders and Corporate Financial Performance, and Capital Structure' 2013 International Journal of Nonlinear Science 235.

37 Kopits supra $\mathrm{n} 32$ at 627.

38 La Porta et al. 'Corporate Ownership around the World' 1999 The Journal of Finance 477; Claessens et al. 'Disentangling the Incentive and Entrenchment Effects of Large Shareholdings' 2000 Journal of Financial Economics 82.

39 Faccioa \& Lang 'The ultimate ownership of Western European corporations' 2002 Journal of Financial Economics 393; Xia 'Founder Control, Ownership Structure and Firm Value: Evidence from Entrepreneurial Listed Firms in China' 2008 Journal of Accounting Research 32; Zhu et al. 'A Regression Analysis on Ultimate Shareholders and Corporate Financial Performance, and Capital Structure' 2013 International Journal of Nonlinear Science 228. 
strategic activities and headquarter functions. ${ }^{40}$ For purposes of this article, an entity that fulfils this role is referred to as a controlling entity.

Below the controlling structure, a multinational group would consist of subsidiaries or branches, either newly established or acquired through cross-border acquisition activities. ${ }^{41}$ The roles of these entities vary depending on the resources and markets available in the different locations where such entities are situated. ${ }^{42}$ Functions typically carried out at different locations by lower level group entities are likely to be operational and could range from securing of materials or inputs, sale and distributions of goods or services, group service functions and research and development activities. ${ }^{43}$ Integration or expansion of activities through entities in multiple locations may be vertical, with functions feeding into each other in the value chain, or horizontal, where the location, protectionist barriers, transport costs or other peculiarities of local demand may demand duplication of functions. ${ }^{44}$ For purposes of this article, an entity fulfilling this role is referred to as an operational or controlled entity.

\section{Definition of Connected Person in Relation to a Company}

The definition of connected persons, as contained in section 1(1) and explained in Interpretation Note 67 , should be considered in light of this composition and operation of multinational groups. In relation to a company, the definition distinguishes between connected persons that are companies and other persons.

Any company is considered to be connected in relation to another company if it forms part of a group of companies where a controlling company holds more than 50 per cent of the shares of a company and such controlling company, together with its controlled companies, hold more than 50 per cent of the shares of the company in question. ${ }^{45}$ This definition recognises a structure with a controlling 'parent' or company which corresponds to the centrally controlling structure identified from the literature. ${ }^{46}$ The literature in paragraph 221 suggested that, in practice, the structure would consist of controlled operational entities in various geographical areas. The South African entity subject to section 31 could either be an investor (controlling company) or a controlled company. The relationship and the role of the South African entity that is subject to the transfer pricing adjustment can be distinguished for

40 Crescenzi et al. 'Innovation Drivers, Value Chains and the Geography of Multinational Firms in European Regions' 2012 London School of Economics and Political Science Europe in Question Discussion Paper Series (LEOS) 5; Naiping et al. supra $\mathrm{n} 36$ at 235.

41 Barrios et al. International Taxation and Multinational Firm Location Decisions: European Communities (2009) 2.

42 Guillen Understanding and Managing the Multinational Firm (2006) 1.

43 OECD supran 3 at 14.

44 SARS Practice Note 7 supra $\mathrm{n} 2$ at 5.

45 Par (d)(i) of the definition 'connected person' in section 1(1) of the Act.

46 Kopits supra n 32 at 626. 
purposes of the connected person definition as being a controlling group company (i.e. a company that holds the shares in the other) or a controlled group company (i.e. a company whose shares are held by the other), as described in the definition of 'group of companies' in section 1(1).

The definition also covers the scenario where another company holds at least 20 per cent of the equity shares or voting rights of the company subject to the transfer pricing adjustment. ${ }^{47}$ As paragraph (e) of the definition effectively requires application in both directions of the relationship, this requirement may apply to a resident company having to make the transfer pricing adjustment in respect of a transaction with an investor or in an investee relationship where the interest held by the resident company is less than 50 per cent. The presence of minority shareholders generally causes transactions to be closer to arm's length terms, depending on the role and influence of the minority shareholder. ${ }^{48}$ It is submitted that non-arm's length terms and conditions in a relationship with an interest of less than 50 per cent shareholding is unlikely given the loss in value to external parties that may be suffered should value be shifted to such an entity. Relationships involving interests of between 20 and 50 per cent were therefore not considered in this analysis.

The last component of the definition that applies between two companies is where a company is managed or controlled by a connected person in relation to the resident company, being subject to the transfer pricing adjustment, or by a connected person in relation to such a connected person. ${ }^{49}$ In this context, 'managed' refers to being responsible to run the business and control - as referring to de facto control - being evident because of the presence and influence on the company's affairs. ${ }^{50}$ This interpretation is unlikely to refer to a relationship where either of the entities invested in the other entity or controls the other entity. As such, it is submitted that the relationship refers to two entities under common control or management.

In relation to persons other than a company, a person that holds at least 20 per cent of the equity shares or voting rights in such company is considered to be a connected person. ${ }^{51}$ As the requirement relates to shareholding in a company, with the resident company being the only company in this equation, this component of the definition is likely to refer to the other person being part of the ownership structure of the group, as opposed to an operational unit. It is therefore submitted that in this context the company, being subject to the secondary transfer pricing

47 Par (d)(v) of the definition of 'connected person' in section 1(1) of the Act.

48 OECD supran 1 at 115.

49 Par (d)(vA) of the definition of 'connected person' in section 1(1) of the Act.

50 Par 3.5.5 of SARS Interpretation Note (IN) No. 67 to the Act: Connected Persons (2012) 22.

51 Par (d)(iv) of the definition of 'connected person' in section 1(1) of the Act. 
adjustment, will arguably fulfil the role of investee as opposed to the investor.

\section{Economic Reasons and Motives for Transfer Pricing in Multinational Groups of Companies}

Literature in the field of business and financial management suggests that multinationals have both internal (managerial) and external (financial) motivations when setting a transfer price. ${ }^{52}$ Minimisation of tax liabilities, achieving goal congruence and the motivation of management effort are some of the most important objectives of transfer pricing within a group. ${ }^{53}$ Not all transactions that require a transfer pricing adjustment would necessarily be motivated by obtaining a tax benefit. Section 31(2) merely requires that a tax benefit be derived, but does not go as far as requiring a determination of the motive for the nonarm's length terms and conditions. This section of the article explores motives and reasons, other than a tax saving, that may affect transfer pricing. Where non-tax motives exist in setting the transfer price, the tax treatment should provide an outcome that is not clearly contrary to such motives.

\section{Internal Motives}

\section{Performance management and evaluation}

Ultimately the overall objective of a multinational group is to maximise the profit of the group as a whole, as opposed to the performance of each component of the group. ${ }^{54}$ This requires performance to be managed from the bottom of the structure upwards by evaluating the performance of the divisional managers and the divisions individually. ${ }^{55}$ The process units in the structure may be evaluated as individual profit centres and assessed on its profits. ${ }^{56}$ Pricing negotiations by independently assessed business units should, in principle, result in the pricing approximating an arm's length pricing arrangement due to the bargaining and individual interests at stake as this simulates an open market environment.

Evidence of hard bargaining alone may however not necessarily be sufficient to conclude that the transaction is at arm's length. ${ }^{57}$ Given an

52 Eden \& Reuter Transfer price manipulation (2012) 210; Bernard et al. 'Transfer pricing by U.S.-based multinational firms' 2006 National Bureau of Economic Research 2.

53 Horngren et al. Cost Accounting - a managerial analysis (2015) 883.

54 Hirshleifer 'On the economics of transfer pricing' 1956 The Journal of Business 172; Hirshleifer 'Economics of the divisionalised firm' 1957 The Journal of Business 100.

55 Cools et al. 'Management control in the transfer pricing tax compliant multinational enterprise' 2008 Accounting, Organizations and Society 3.

56 Eden International taxation, transfer pricing and the multinational enterprise (2001) 593.

57 Kopits supra $\mathrm{n} 32$ at 626. 
objective of overall group profit maximisation, ${ }^{58}$ minimisation of the overall tax burden impacts positively on the group's overall profitability and may cause performance management to be done on such a basis that it encourages the lowering of the overall tax liability. ${ }^{59}$ Decisions made by group management, including performance objectives and related pricing arrangements, may be developed to influence the allocation of profit, capital components and cash flow across the centres that can achieve this outcome. ${ }^{60}$

Therefore, it is submitted that performance management and evaluation as a primary motivation should not result in transfer pricing manipulation. Where this is however used as one of the tools to lower the overall tax burden, with actual performance management being of secondary importance, this may be a motivation to manipulate transfer pricing. It is therefore submitted that performance management is unlikely to motivate non-arm's length pricing for reasons other than obtaining a tax saving. As such, this motive is not considered further as part of the conceptual analysis.

\section{Operational Objectives}

\section{Market entry}

Subsidiaries, amongst others, could be established by a multinational group in order to gain entry into a new market. ${ }^{61}$ An entry strategy of the group could be to charge lower transfer prices to, or put differently, to subsidise the subsidiary. ${ }^{62}$ The OECD aptly describes a market entry strategy as the reduction in current profits in anticipation of increased future profits. ${ }^{63}$ Market entry gained through a wholly-owned subsidiary is likely to lead to a normal profit allocation and return on investment in the long-run. 64

\section{Efficiency considerations}

In addition to assisting a subsidiary to enter a new market at a competitive price, pricing may also be used to allow a market leader to

58 Idem 597; Cristea \& Nguyen Transfer Pricing by multinational firms: new evidence from foreign firm ownerships (2013) 27 available from http:// pages.uoregon.edu/cristea/Research_files/transfprice.pdf (accessed 201405-13).

59 OECD supra $\mathrm{n} 1$ at 31.

60 Steens How managerial transfer pricing can help create economic value (2011) 75.

61 Birkinshaw \& Hood 'Multinational subsidiary evolution: Capability and charter change in foreign-owned subsidiary companies' 1998 Academy of Management Review 773.

62 Schjelderup \& Sørgard 'Transfer pricing as a strategic device for decentralised multinationals; 1997 International Tax and Public Finance 278; Porter Competitive advantage: creating and sustaining superior performance (1985) 12 .

63 OECD supra $\mathrm{n} 1$ at 50.

64 Twarowska \& K?kol International business strategy - reasons and forms of expansion into foreign market (2013) 1007. 
institute price reductions in response to slack demand or declining markets in a geographic area. ${ }^{65}$ This, however, may also be a strategy to obtain further growth in a market in which the entity or group already functions. Companies could be enabled to institute price reductions if other companies in the group charge a lower transfer price to the company. ${ }^{66}$ This decision may be taken at a central level where the group's operating strategy is determined and merely implemented or enforced on the level of operating companies. ${ }^{67}$ Such a pricing strategy indirectly provides financial assistance to the company and as a result, benefits the group as a whole. ${ }^{68}$

\section{External Motives}

\section{Difference in Corporate Income Tax Rates and the Avoidance of Duties}

Opportunities exist for multinational groups to exploit differences in policies and tax rates between countries in order to minimise their overall tax burden, thereby maximising the ultimate shareholder profits. ${ }^{69}$ This exploitation may involve the artificial shifting of profits ${ }^{70}$ or, by the misclassification of products, to circumvent export duties. ${ }^{71}$ Such a shift in profits is often accompanied by the repatriation of such profits into the group or to the shareholder in a different form, for example, dividends that may be subject to tax at a lower rate or be exempt from tax. ${ }^{72}$ It is submitted that this type of profit shifting is precisely the activity that transfer pricing provisions in tax legislation aim to prevent. ${ }^{73}$ As such, this motivation for the pricing arrangement does not constitute a valid business reason, other than obtaining a tax benefit, to be factored into the conceptual analysis. Arguably, this is the case even when the reason for the manipulation relates to circumvention of duties, despite the fact that such duties do not meet the definition of tax as per the Act that only relates to income tax, as the underlying reason cannot be linked to another valid non-tax business objective.

65 Cravens 'Examining the role of transfer pricing as a strategy for multinational firms' 1997 International Business Review 134.

66 Schjelderup \& Sørgard 1997 International Tax and Public Finance 278.

67 Kind et al. "Corporate tax systems, multinational enterprises, and economic integration’ 2005 Journal of International Economics 510.

68 Ibid

69 Lin \& Chang 'Motives of transfer pricing strategies - systemic analysis' 2010 Industrial Management \& Data Systems 2; Cristea \& Nguyen supra n 58 at 26.

70 Li \& Balachandran 'Effects of differential tax rates on transfer pricing’ 1996 Journal of Accounting, Auditing and Finance 191.

71 Goetzl 'Why don't trade numbers add up?' (2005) International Tropical Timber Organisation (ITTO) Tropical Forest Update 9.

72 Kocieniewski 'G.E.'s strategies let it avoid taxes altogether' The New York Times (2011-03-24) available from http://www.nytimes.com/2011/03/25/ business/economy/25tax.html?pagewanted $=$ all\&_r $=0$ (accessed 2014-0424).

73 OECD supra $n 1$ at 32 


\section{Country and Currency Related Motives}

Many countries, in particular on the African continent, have some form of exchange control regulation aimed at maintaining the stability of its own currency and managing its balance of payments. ${ }^{74}$ Restrictions imposed by such measures however limit the accessibility of funds in a multinational group. Circumvention of foreign exchange control restrictions in order to prevent losses due to the devaluation of the currency of a country may play an important role in the setting of transfer prices by multinational groups. ${ }^{75}$ Pricing of related party transactions can be used as a method of moving profits (value) in a form other than cash, for example, attempting to overcharge for management services rendered rather than drawing funds as dividends, despite such restrictions. $^{76}$ The OECD views foreign exchange restrictions as a governmental pressure and confirms that this may cause transfer prices to be manipulated due to cash flow requirements of multinational groups. ${ }^{77}$ A closely related risk is country risk. Country risk occurs in the following two forms: Risk of sovereignty (the risk of possible expropriation and profit restriction) and transfer or convertibility risk (when the central bank cannot mobilise enough foreign reserves in order to convert financial funds in the local currency to a foreign currency). ${ }^{78}$ The presence of such risks may lure multinational groups into attempting to transfer wealth out of a country to avoid the erosion of its future value in times of political uncertainty. ${ }^{79}$ It is submitted that this motive is not primarily driven by the tax benefit to be obtained from the pricing, even though the tax benefit may play a secondary role. As such, this motive is considered in the conceptual analysis.

\section{Conceptual Analysis of the Treatment in Section 31(3)(i)}

Section 31(3)(i) deems any transfer pricing adjustment by a resident company arising from a transaction with a connected non-resident or a connected resident's foreign permanent establishment to be a deemed dividend. In this part of the article it is considered whether it is

74 Douglas Are exchange controls a benefit or detriment to African business? (2014) 1; World Bank Group Restrictions on Foreign Investors/Currency Exchange Controls available from http://ppp.worldbank.org/public-privatepartnership/legislation-regulation/framework-assessment/legal-environmen t/foreign-investor-currency-exchange-restrictions\#CurrencyExchange (accessed 2015-06-05).

75 Chan \& Chow 'An empirical study of tax audits in China on international transfer pricing' 1997 Journal of Accounting and Economics 101.

76 OECD supra $\mathrm{n} 1$ at 214.

77 Idem 55.

78 Petrovi? \& Stankovi? 'Country risk and effects of foreign direct investment' 2009 Economics and Organization 12.

79 Lensink et al. 'Capital flight and political risk' 2000 Journal of International Money and Finance 74; Mohamed \& Finnoff Capital flight from South Africa, 1980 to 2000 (2004) 3; OECD supra n 1 at 215. 
conceptually sound to treat all secondary adjustments by companies as dividends. This analysis is structured to consider the position from the perspective of the two roles that the resident company may fulfil in a multinational group (as identified in paragraph 22 ), namely an operating or controlled company in paragraph 31 and controlling company in paragraph 32 . This is done to establish the direction of the likely flows of value, which is a critical factor in the conceptual analysis. For each of these roles, the appropriateness of the dividend treatment is considered by having regard to the non-tax motives for pricing, as identified in paragraph 23 , and the characteristics of the alternatives for underlying transactions, as considered in paragraph 21 .

\section{Resident Company Performs the Role of an Operating Entity Within the Group}

Operations within a multinational group are likely to take place in operating subsidiaries located across various geographical regions. In the context of the definition of a connected person in the Act, such subsidiaries are likely to be connected to the parent, or the central holding structure, as controlled companies contemplated in paragraph (d)(i) of this definition. Such an entity is connected in relation to both the central holding entity as well as other operating or controlled entities held within the same structure. Paragraph $(\mathrm{d})(\mathrm{v})$ of the definition also refers to structures where entities, other than companies (for example a trust), invests and holds shares in a company. Similarly, paragraph (d)(vA) of the definition results in entities that form part of the same structure by reason of ultimately being controlled or managed by the same persons to be connected. For purposes of this analysis, it is assumed that where the South African resident entity subject to transfer pricing is connected in relation to the counterparty to a transaction, firstly, as investee or, alternatively, by reason of being commonly controlled, that such entity fulfils the role of an operating entity in the multinational structure. In such a case the benefit (underpriced goods or services or overpayment for supplies made to it) will be transferred horizontally to another related operating entity under common control or alternatively upwards into the holding structure for the owners of the structure to be able to extract such a benefit.

Based on the review of the literature on the characteristics of a dividend, as considered in paragraph 211 , a dividend would be something of value, whether cash or otherwise, that is transferred to a person in such a manner that the shareholder of the company benefits, directly or indirectly through another related entity, without the distributing entity receiving equivalent value in exchange for such transfer. It is submitted that where the resident operating company transfers value, either horizontally or upwards into the holding structure, such benefit is extracted from the entity for the benefit of its owner.

This transfer may be direct, in the case of an upward distribution, or indirect, in the case of a horizontal shift of value to an entity in which the 
ultimate owner has an interest and from which the value can be extracted by the ultimate owner. If a transfer pricing adjustment is required, this implies that the resident company does not receive something of equivalent value in exchange for what is given up. In light of the fact that value could ultimately be extracted to the top of the structure where the operations are owned, as indicated in paragraph 22 1 , there is no indication, nor any reason, why such value would be repaid to the resident operating company in future. This lack of an agreement or implied repayment terms eliminates the benefit from being treated as a constructive loan. As the resident transferor has no apparent stake in the business and risks of the transferee, it is submitted that a value shifted through transfer pricing by a resident company in this context lacks this essential characteristic of an equity contribution. Based on the characteristics of the three alternatives it is submitted in the context of a resident company being an operating or controlled entity in a multinational structure that the treatment of the value transferred as a dividend appears to be conceptually sound.

As part of an integrated product or service value chain of a multinational enterprise it is submitted that the resident company subject to section 31 may be involved in non-arm's length pricing arrangements aimed at achieving overall efficiency of the group. This may, in certain instances as, indicated in paragraph 231 , require the South African entity to subsidise another operational entity in which case a tax benefit may arise in the hands of the South African entity. In this context, it is submitted that the beneficiary of the value transferred is likely to be the operating entity with which the resident company transacts (i.e. horizontal transfer). This does not alter the direction and nature of the value flow considered above.

Regarding the external motives for such pricing arrangements, the goods or services supplied or acquired by the resident company may be part of a scheme to withdraw value indirectly from a location with high currency and country risk (see par 232 ). However, it is submitted that such a withdrawal strategy, involving the flow of goods or services, would still take place horizontally in the case of an operating entity forming part of the value chain. Given that the controlling structure of a multinational group would generally be located in a democratic country or one with relatively low country risk, ${ }^{80}$ an upward extraction of value may be used to remove funds that originated from activities in a high-risk regime. A downward redistribution of funds may not necessarily achieve the desired outcome, as this would mean that the funds or value would eventually have to pass through the high-risk regime again to be extracted. As the transfer pricing regime in section 31 is aimed at the artificial shifting of funds that reduce profits in South Africa, the motive of pricing manipulation to circumvent currency or country risk will arguably only result in South African transfer pricing adjustments if the South African environment or currency is viewed as posing such a risk 
which value has to be shifted away from. It is therefore submitted that this motive supports the direction of the value flow as indicated above.

Based on the position of such an operating resident company in a multinational structure and the fact that value is likely to be shifted horizontally or upwards, based on the non-tax motives that may be relevant in determining pricing arrangements, it is submitted that the treatment of the secondary adjustment as a constructive dividend, which is subject to dividends tax, is conceptually sound in the case of a South African resident operating company, as value is shifted away from South Africa to a location from which the ultimately shareholders or owners will benefit from it.

\section{Resident Company Performs the Role of Investor in the Group}

The definition of a 'connected person in the Act, in particular paragraph (d)(i) read with the definition of group company, includes the scenario where a connected person's relationship is triggered by the fact that the resident company acts as an investor in other companies (this position differs from that considered in paragraph 31 where the resident company was connected to the counterparty that it deals with by reason of being an investee or commonly controlled). In this instance, the resident company, in its role as investor, may perform the function of being the central point of control in the structure, or at least an intermediary point of control. This role of South African companies is supported by the South African National Treasury's drive to make South Africa attractive as a gateway for holding companies to invest and expand into Africa. ${ }^{81}$ It is submitted that paragraphs $(\mathrm{d})(\mathrm{vA})$ and $(\mathrm{d})(\mathrm{v})$ are both only triggered by a relationship where the company is the investee or is controlled by another person. Based on the literature review in paragraph 221 , control of a multinational group structure is likely to be concentrated in a few entities in a pyramidal structure while there may be a larger number of operating entities.

A key characteristic of a dividend, as indicated in paragraph 211 , is that something of value, whether cash or otherwise, is transferred to a person in such a manner that the shareholder of the company benefits, directly or indirectly, through another related entity. In relation to the investor resident company itself, it becomes questionable whether this element will always be met. It is submitted that the direction of the flow of value subject to the transfer pricing adjustment is critical. If the adjustment takes place horizontally to an operating entity which is directly controlled by another controlling entity or upwards, to the shareholder of the controlling or investor entity, the transaction will meet this requirement and the treatment as a dividend would be conceptually

81 National Treasury Explanatory memorandum on the Taxation Laws Amendment Bill 2013 (2013) 1; PWC International transfer pricing 2013/2014 (2013) 192. 
sound. If however the value is transferred downwards in the group structure, no real benefit would have been extracted from the sub-part of the group owned by the resident investor company's shareholder, either directly or indirectly. The value stays in or below the resident company in the structure, and would arguably still have to be extracted for the benefit of the resident company's shareholder in future. This future extraction would be subject to a dividend withholding tax. If the downward transaction also attracts dividends tax, the same value may potentially be subject to dividends tax twice. This unintended effect stems from the fact that a deemed dividend is not a conceptually sound outcome on a downward transaction with a controlled company.

Therefore, it is submitted that the treatment of value transferred by a resident investor company, which attracts a transfer pricing adjustment, is conceptually sound only if the value is transferred horizontally or upwards, but not when shifted to an entity in which the resident company holds an interest. In light of the fact that the secondary adjustment is only a hypothetical transaction, the critical element of debt, as determined in paragraph 213 , to have an obligation to repay the benefit is unlikely to exist. Such a transfer of value to an investee, however, is likely to display the defining characteristics of an equity contribution, as set out in paragraph 212 , in that the value is shifted or contributed to an entity in which the investor has an interest in the growth but also the risk of the business. As controlling entity in the structure, the resident company should have a controlling or management influence over the benefit transferred and its repatriation or utilisation. Lastly, whether the value flows back to the resident investor or not, depends on the performance of the investee and is likely to be discretionary. It is submitted that in this instance, the transfer of value has the characteristics of an equity contribution, rather than those of a dividend.

The consideration of reasons and motives for horizontal or upward transfers by such a controlling entity should be similar to those discussed in paragraph 31 and are not repeated here. In the context of a controlling company transferring value downwards in the structure, it is submitted that the internal motive of a pricing arrangement to enable market entry or otherwise provide assistance to the investee, as identified in paragraph 231 , may feature strongly. Treatment of such a transfer as an equity contribution will be consistent with the characteristics identified as the value shifted to the investee is likely to be at risk, if such investee requires assistance, but may increase the value of the resident company's interest should the assistance be successful. It is submitted that this motive for transfer pricing does not alter the direction of the flow of value as discussed above. A potential double dividends tax implication, as indicated above, that may arise if the South African controlling entity contributes towards controlled entities in the form of startup assistance through pricing may impact adverse on the use of South Africa as an investment gateway into the rest of Africa. 
The external, non-tax, motive for pricing arrangements identified in paragraph 232 , namely extraction of value from high country or currency risk environments, should in principle not apply in a downward direction from the controlling company to the controlled company as this would imply that the central controlling company is situated in the highrisk environment, which is highly unlikely to be the case based on the views of commentators that such entities are normally located in stable democratic countries. ${ }^{82}$ This motive, therefore, has not been considered further in the context of downward transactions by controlling companies.

\section{Conclusion on the Conceptual Analysis}

Based on the analysis performed in this article, it is submitted that the treatment of a transaction that requires a secondary adjustment as a deemed dividend would generally be conceptually sound taking into account the critical characteristics of a dividend, compared to those of an equity contribution or loan, the relationships between entities in a multinational structure that may cause such entities to be connected persons in relation to each other, as well as the motives and reasons that may exist for non-arm's length pricing, other than to obtain a tax benefit.

This treatment is however not conceptually sound in the case where value is transferred downwards by an investor company to an investee company. Such a transfer would take place between entities that are connected in relation to each other by reason of the transferor of the value being a controlling company, as contemplated in paragraph (d)(i) of the definition of connected person in the Act read with the definition of group company, to a controlled company, as contemplated in those same definitions. If this adjustment is treated as a deemed dividend, this may result in the same value potentially being subject to dividends tax twice. The analysis performed in this article suggests that it would be more appropriate from a conceptual perspective to treat a transfer of value in these circumstances as a deemed equity contribution rather than a deemed dividend.

The contribution of value or funds to an investee has no direct or immediate tax implications under South African tax law other than establishing a cost for such investment. Unlike a deemed dividend that imposes a further tax burden on the taxpayer, this cost of the investment will have the effect of reducing taxable gains (whether of a revenue or capital nature) in future. It is questionable whether such an adjustment in favour of a taxpayer, despite being conceptually sound, can be required by a transfer pricing provision, which is essentially an antiavoidance measure. However, an exemption from the provisions of section 31(3)(i) may be warranted in light of the potential double dividend tax this creates in a structure. It is therefore recommended that

82 Guillen supra $\mathrm{n} 42$ at $8 \& 26$ 
further research be performed to establish whether the current framework of secondary transfer pricing adjustments in section 31(3)(i) would be able to accommodate an exception from the deemed dividend treatment without such an exception creating opportunities for abuse or avoidance of the secondary adjustment in circumstances where the deemed dividend treatment would have been appropriate. 